\title{
Assessment and promotion of social responsibility of business in the development of rural areas of the mining region
}

\author{
Tatyana Yurzina ${ }^{1, *}$, Nikolay Shalanov ${ }^{2}$, and Piotr Kosinskiy ${ }^{1}$ \\ ${ }^{1}$ T.F. Gorbachev Kuzbass State Technical University, 28 Vesennyaya, Kemerovo, 65000 \\ ${ }^{2}$ Siberian University of Consumer Cooperation, 26 K.Marks Avenue, Novosibirsk, 630087
}

\begin{abstract}
In modern conditions, business development accompanied by its social responsibility, which is important for rural areas of the mining region. Businesses operating in rural areas use their labor resources and social infrastructure. Intensive development of the mining industry accompanied by both negative environmental consequences and impact on the socio - economic development of territories that, due to insufficient funds in local budgets, are not able to solve many existing problems. The search for mechanisms for the development of rural areas in combination with social responsibility of business is the key to its successful functioning, one of the conditions for which is a harmonious combination of its interests and the interests of rural areas. This combination can manifest itself in business investment in rural development. However, businesses must be motivated to invest. This motivation is the level of investment attractiveness of rural areas. The ratio between the levels of investment attractiveness of the territory and the investment potential of the business forms such a category as the level of motivation for the implementation of social responsibility of the business. At the same time, the growth of business investment potential contributes to increasing the level of investment attractiveness of rural areas. Thus, increasing motivation to implement social responsibility of business is a condition for its stimulation. To solve this problem, the authors propose a method for integral assessment of motivation for implementing social responsibility based on an algorithm for calculating it based on a set of indicators. It was conclude that increasing the investment attractiveness of the territory affects the growth of the level of motivation for the implementation of social responsibility of business, thus ensuring the harmonious development of the business and the territory of its location.
\end{abstract}

\section{Introduction}

The most important issue in assessing the activities of business representatives is to determine the effectiveness of the functioning of both objects and subjects of its sphere of

* Correspondent author: Yurzina $\mathrm{t} @$,mail.ru 
responsibility. If we talk about business activity within an enterprise, it acts as both an object and a subject. Its subjectivity determined by the formation of the production base for increasing the wages of employees as an economic component. At the same time, the company must provide normal conditions for employees in terms of social and environmental components. In this regard, the object of social responsibility is the company's personnel. It is quite possible to measure the level of social responsibility of a business based on a set of these indicators by calculating an integrated assessment of the level of development of an enterprise, where economic, social and environmental factors were using as indicators.

It is much more difficult to solve the problem of determining the social responsibility of business to the municipality in which the business is located. Although the term "social responsibility of business" is a qualitative characteristic, it still requires a quantitative assessment.

Based on statistical reporting, the social responsibility of business to the territoryfixed by law and acts as tax deductions to the municipal budget. However, if we talk about social responsibility, it should be determined on a voluntary basis[1-13].

The purpose of the work is to assess and promote social responsibility of business in the development of rural areas of the mining region.

The study of social responsibility of business and its impact on the development of rural areas of the mining region and the development of methods for assessing and stimulating social responsibility of business are the objectives of this study.

The research object is the rural territories of the Kemerovo region, which is a typical mining region.

The research carried out using the methods of comparative, economic analysis and economic-mathematical method.

\section{Discussionand results}

To solve this problem, it is necessary to determine the objectivity and subjectivity of social responsibility of business within the author's paradigm. In this case, the enterprise acts as the subject, and the territory acts as the object. Social responsibility of business, in our opinion, will be the investment of the enterprise in the development of the territory.

In this regard, it is necessary to quantify the ability and motivation of the subject to make investments. The possibility of investment activity of the subject proposed to evaluate such an indicator as an integral assessment of the investment potential of the enterprise, which is denoted by $J_{p t}$. At the same time, for investment activity, the subject of investment must have motivation. As a motivation, we suggest using the investment attractiveness of the territory, the level of which we will designate through $J_{p r}$. Then to assess the level of social responsibility of the business, we use an integrated assessment of the motivation for implementing social responsibility. So,

$J_{p t}$ - the level of investment potential of the enterprise;

$J_{p r}$-the level of investment attractiveness of the territory;

$J_{m}$-the level of motivation for implementing social responsibility of the business.

The value $J_{m}$ acts as a causal relationship between the investment potential of the subject and the investment attractiveness of the investment object. The level of motivation of social responsibility of business within the framework of the paradigm proposed to be defined as the ratio of the level of investment attractiveness of the territory to the level of investment potential of the enterprise:

$$
J_{m}=\frac{J_{p r}}{J_{p t}}
$$


If $J_{m}=1$, then the ability of the territory to return the amount going to the investment with an increment in the amount of the Bank's loan interest coincides with the ability of the enterprise to invest in the development of the territory. If $J_{m}>1$, the company will have full confidence in paying off the investment debt in increments. If $J_{m}<1$, the company is not $100 \%$ sure of paying off the debt and the value $\mathrm{R}=1-J_{m}$ will represent the risk of investing the territory.

To solve this problem, it is necessary to have a methodological tool that acts as an algorithm for calculating the integral assessment of a set of indicators.

Algorithm for calculating the integral score based on a set of indicators. [14, 15]

The algorithm has a two-level structure.

Let

$x_{j k}^{0}-$ actual value of the $\mathrm{j}$ - $\mathrm{j}$-th indicator of the $\mathrm{k}$-th block $(\mathrm{J}=1, \mathrm{n} ; \mathrm{k}=1, \mathrm{~m})$;

$x_{j k}^{*}$ - reference value of the $\mathrm{j}$ - th indicator of the k-th block.

Defining integrated assessment within blocks:

The relative measure of achievement of the reference value by the $j$-th indicator in the $\mathrm{k}$-th block is calculated:

$$
\alpha_{j k}=\frac{x_{j k}^{0}}{x_{j k}^{*}}
$$

1.2. The significance of the $\mathrm{j}$-th indicator in the complex assessment of the $\mathrm{k}$-th block is Calculated:

$$
\beta_{j k}=\frac{\alpha_{j k}}{\sum_{j=1}^{n} \alpha_{j k}} ;
$$

1.3. The complex estimation of the k-th block is Determined:

$$
C_{k}^{0}=\frac{1}{n} \sum_{j=1}^{n} \alpha_{j k}
$$

2.1. The relative measure of achievement of the reference value by the $k$-th block is Calculated:

$$
\beta_{k}=\frac{\mathrm{C}_{k}^{0}}{\mathrm{C}_{k}^{*}}
$$

2.2. The significance of the $\mathrm{k}$-th block in the integral estimation is Determined:

2.3. Being an integral estimation:

$$
\alpha_{k}=\frac{\beta_{k}}{\sum_{k=1}^{m} \beta_{k}}
$$

$$
C^{0}=\frac{1}{m} \sum_{k=1}^{m} \mathrm{C}_{k}^{0}
$$

In the case of three, four, or more levels of algorithms, the procedure is repeated within the second level, and the first remains unchanged.

A system of indicators for evaluating the investment potential of an enterprise:

1. Economic condition:

1.1. The average monthly wage, thousand RUB.

1.2. Investments in fixed assets per 1 employee, thousand rubles.

1.3. Net profit per 1 employee, thousand rubles.

1.4. Profitability level, \%.

2. Expenses on the social sphere:

2.1. The expenditure on social services per 1 employee, thous. rub.

2.2. Charity expenses per 1 employee, thousand rubles.

2.3. The cost of development of the area per 1 employee, rub.

3. The cost of the environment:

3.1. Spending on the environment per 1 worker, thousand rubles.

3.2. Costs for remediation of land per 1 worker, thousand rubles. 
Indicators of the company's investment potential presented in both absolute and relative terms. Thus, the expenses for the development of the territory are absolute. However, the remaining indicators are taken in relative terms, since they will be more informative if they are calculated for 1 employee.

It should be noted that this system of indicators can be supplemented and changed.

A system of indicators for assessing the investment attractiveness of the territory:

1. Economic condition:

1.1. The volume of per capita gross domestic product, thousand rubles.

1.2. The number of small enterprises units.

1.3. Per capita investment in the real sector of the economy, thousand rubles.

1.4. Per capita consolidated budget, thousand rubles.

1.5. The average monthly wage, thousand rubles.

2. State of the social sphere:

2.1. The average per capita turnover, thousandrubles.

2.2. The volume of per capita paid services, thousand rubles.

2.3. Per capita availability of housing, sq. $\mathrm{m}$.

2.4. Per capita current expenditure on social services, thousand rubles.

2.5. Per capita investment in the social sector, thousand rubles.

3. The cost of the environment:

3.1. Per capita current environmental expenditure, thousand rubles.

3.2. Per capita investment in environmental protection, thousand rubles.

Most of the indicators are also presented in relative terms, since these territories will be more informative per capita than in absolute terms. This indicator system can also be supplemented or changed. Statistical information is provided in table 1 .

Table 1. The actual and reference values of indicators of investment potential of the enterprise.

\begin{tabular}{|l|c|c|c|}
\hline \multicolumn{1}{|c|}{ Indicators } & Designation $\left(x_{j k}\right)$ & $\begin{array}{c}\text { The actual } \\
\text { value }\left(x_{j k}^{0}\right)\end{array}$ & $\begin{array}{c}\text { The } \\
\text { reference } \\
\text { value } \\
\left(x_{j k}^{*}\right)\end{array}$ \\
\hline \multicolumn{2}{|c|}{ Economic condition } \\
\hline Average monthly salary, thousand rubles & $x_{11}$ & 55.4 & 60.0 \\
\hline $\begin{array}{l}\text { Investments in fixed assets per 1 } \\
\text { employee, thousand rubles }\end{array}$ & $x_{21}$ & 1.31 & 1.6 \\
\hline $\begin{array}{l}\text { Net profit per 1 employee, thousand } \\
\text { rubles }\end{array}$ & $x_{31}$ & 1.64 & 2.0 \\
\hline Level of profitability, \%. & $x_{41}$ & 22.0 & 25.0 \\
\hline \multicolumn{2}{|c|}{ Expenses on the social sphere } \\
\hline $\begin{array}{l}\text { Social expenditures per 1 employee, } \\
\text { thousand rubles }\end{array}$ & $x_{12}$ & 7.11 & 7.50 \\
\hline $\begin{array}{l}\text { Charity expenses per 1 employee, } \\
\text { thousand rubles }\end{array}$ & $x_{22}$ & 0.78 & 0.90 \\
\hline $\begin{array}{l}\text { The cost of development of the area per 1 } \\
\text { employee, rubles }\end{array}$ & $x_{32}$ & 7.82 & 10.0 \\
\hline \multicolumn{3}{|c|}{ The cost of the environment } \\
\hline $\begin{array}{l}\text { Environmental expenses per 1 employee, } \\
\text { thousand rubles }\end{array}$ & $x_{13}$ & 0.18 & 0.25 \\
\hline $\begin{array}{l}\text { Land reclamation costs, per 1 employee, } \\
\text { thousand rubles }\end{array}$ & $x_{23}$ & 1.70 \\
\hline
\end{tabular}


Table 2. Actual and reference values of investment activity indicators attractiveness of the territory.

\begin{tabular}{|l|c|c|c|}
\hline \multicolumn{1}{|c|}{ Indicators } & $\begin{array}{c}\text { Designation } \\
\left(x_{j k}\right)\end{array}$ & $\begin{array}{c}\text { The actual } \\
\text { value }\left(x_{j k}^{0}\right)\end{array}$ & $\begin{array}{c}\text { The reference } \\
\text { value }\left(x_{j k}^{*}\right)\end{array}$ \\
\hline \multicolumn{3}{|c|}{ Economic condition } \\
\hline $\begin{array}{l}\text { Average per capita volume of gross product, } \\
\text { thousand rubles }\end{array}$ & $x_{11}$ & 358.8 & 370.0 \\
\hline Number of small businesses, units & $x_{21}$ & 64 & 80 \\
\hline $\begin{array}{l}\text { Average per capita investment in the real } \\
\text { economy, thousand rubles }\end{array}$ & $x_{31}$ & 360.91 & 380 \\
\hline Per capita consolidated budget, thousand rubles & $x_{41}$ & 53.31 & 56.0 \\
\hline Average monthly salary, thousand rubles & $x_{51}$ & 38.25 & 45.0 \\
\hline \multicolumn{3}{|c|}{ State of the social environment } \\
\hline Average per capita turnover, thousand rubles & $x_{12}$ & 41.08 & 45.0 \\
\hline $\begin{array}{l}\text { Per capita volume of paid services, thousand } \\
\text { rubles }\end{array}$ & $x_{22}$ & 6.37 & 7.0 \\
\hline Average per capita housing supply, sq. m. & $x_{32}$ & 29.32 & 32.0 \\
\hline $\begin{array}{l}\text { Average per capita current expenditures on social } \\
\text { services, thousand rubles }\end{array}$ & $x_{42}$ & 39.12 & 44.0 \\
\hline $\begin{array}{l}\text { Average per capita investment in the social } \\
\text { sphere, thousand rubles }\end{array}$ & $x_{52}$ & 496.59 & 510.0 \\
\hline \multicolumn{3}{|l|}{ The cost of the environment } \\
\hline $\begin{array}{l}\text { Average per capita current expenditures on } \\
\text { ecology, thousand rubles }\end{array}$ & $x_{13}$ & 3.24 & 3.5 \\
\hline $\begin{array}{l}\text { Average per capita investment in environmental } \\
\text { protection, thousand rubles }\end{array}$ & $x_{23}$ & 3.71 & 4.0 \\
\hline
\end{tabular}

We will perform calculations to determine the integral assessment of the investment potential of the enterprise according to the described algorithm (Table 3).

Table 3. Calculation of a comprehensive assessment of the economic condition of the enterprise.

\begin{tabular}{|c|c|c|c|c|c|c|}
\hline$x_{j 1}$ & $x_{j 1}^{0}$ & $x_{j 1}^{*}$ & $\alpha_{j 1}=\frac{x_{j 1}^{0}}{x_{j 1}^{*}}$ & $\beta_{j 1}=\frac{\alpha_{j 1}}{\sum_{j=1}^{n} \alpha_{j 1}}$ & $\beta_{j 1}=\frac{\alpha_{j 1}}{\sum_{j=1}^{n} \alpha_{j 1}}$ & $\beta_{j 1}=\frac{\alpha_{j 1}}{\sum_{j=1}^{n} \alpha_{j 1}}$ \\
\hline$x_{11}$ & 55.4 & 60.0 & 0.923 & 0.268 & 0.268 & 0.268 \\
\hline$x_{21}$ & 1.31 & 1.6 & 0.819 & 0.238 & 0.238 & 0.238 \\
\hline$x_{31}$ & 1.64 & 2.0 & 0.820 & 0.238 & 0.238 & 0.238 \\
\hline$x_{41}$ & 22.0 & 25.0 & 0.880 & 0.256 & 0.256 & 0.256 \\
\hline$\Sigma$ & & & 3.442 & 1.0 & 1.0 & 1.0 \\
\hline $\mathrm{C}_{1}^{0}$ & & & 0.861 & & & \\
\hline
\end{tabular}

Comprehensive assessment of the economic condition of the enterprise $C_{1}^{0}=0.861$, i.e. the enterprise reached the reference state by $86.1 \%$ for this block of indicators. At the same time, the average monthly salary provides for the achieved state by $26.8 \%$; investments in fixed assets - by $23.8 \%$; net profit - by $23.8 \%$; the level of profitability - by $25.6 \%$.

Table 4. Calculation of the integrated assessment of the investment potential of the enterprise.

\begin{tabular}{|c|c|c|c|c|c|}
\hline$C_{k}$ & $C_{k}^{0}$ & $C_{k}^{*}$ & $\alpha_{k}=\frac{C_{k}^{0}}{C_{k}^{*}}$ & $\beta_{k}=\frac{\alpha_{k}}{\sum_{j=1}^{m} \alpha_{k}}$ & $\begin{array}{c}\beta_{j 2}(\%) \\
\text { importance }\end{array}$ \\
\hline$C_{1}^{0}$ & 0.861 & 1 & 0.861 & 0.341 & 34.1 \\
\hline$C_{2}^{0}$ & 0.866 & 1 & 0.866 & 0.343 & 34.3 \\
\hline$C_{3}^{0}$ & 0.796 & 1 & 0.796 & 0.316 & 31.6 \\
\hline$\Sigma$ & & & 2.523 & 1.0 & 100.0 \\
\hline
\end{tabular}




\begin{tabular}{|l|l|l|l|l|l|}
\hline$C^{0}$ & & & 0.841 & & \\
\hline
\end{tabular}

Integrated assessment of the investment potential of the enterprise for the entire complex of blocks $C^{0}=0.841$, i.e. the enterprise for the entire complex of indicators reached the reference state by $84.1 \%$. The economic condition $34.1 \%$ achieves a benchmark of investment potential; social environment - by $34.3 \%$; environmental condition $-31.6 \%$.

Let's combine all the calculation results into a single table 5.

Table 5. Interpretation of an enterprise's investment potential.

\begin{tabular}{|c|c|c|c|c|c|}
\hline $\begin{array}{l}\text { Integrated } \\
\text { assessment of } \\
\text { investment } \\
\text { potential }\end{array}$ & Block & $\begin{array}{l}\text { Integrated } \\
\text { assessment }\end{array}$ & Importance, $\%$ & Indicator & $\begin{array}{c}\text { Importance } \\
, \%\end{array}$ \\
\hline \multirow{9}{*}{84.1} & \multirow{4}{*}{$\begin{array}{l}\text { Economic } \\
\text { condition }\end{array}$} & \multirow[t]{4}{*}{86.1} & \multirow[t]{4}{*}{34.1} & $x_{11}$ & 26.8 \\
\hline & & & & $x_{21}$ & 23.8 \\
\hline & & & & $x_{31}$ & 23.8 \\
\hline & & & & $x_{41}$ & 25.6 \\
\hline & \multirow{3}{*}{$\begin{array}{l}\text { State of the } \\
\text { social sphere }\end{array}$} & \multirow[t]{3}{*}{86.6} & \multirow[t]{3}{*}{34.3} & $x_{12}$ & 36.5 \\
\hline & & & & $x_{22}$ & 33.4 \\
\hline & & & & $x_{32}$ & 30.1 \\
\hline & \multirow{2}{*}{$\begin{array}{l}\text { Ecological } \\
\text { state }\end{array}$} & \multirow[t]{2}{*}{79.6} & \multirow[t]{2}{*}{31.6} & $x_{13}$ & 45.3 \\
\hline & & & & $x_{23}$ & 54.7 \\
\hline
\end{tabular}

Statistical information for calculating the integrated assessment of investment attractiveness of the territory is presented in Table 6 .

Table 6. Calculation of a comprehensive assessment of the economic condition of a municipality.

\begin{tabular}{|c|c|c|c|c|c|}
\hline$x_{j 1}$ & $x_{j 1}^{0}$ & $x_{j 1}^{*}$ & $\alpha_{j 1}=\frac{x_{j 1}^{0}}{x_{j 1}^{*}}$ & $\begin{array}{c}\beta_{j 1} \\
=\frac{\alpha_{j 1}}{\sum_{j=1}^{n} \alpha_{j 1}}\end{array}$ & $\begin{array}{c}\beta_{j 1}(\%) \\
\text { importance, } \%\end{array}$ \\
\hline$x_{11}$ & 358.8 & 370.0 & 0.970 & 0.215 & 21.5 \\
\hline$x_{21}$ & 64 & 80.0 & 0.800 & 0.177 & 17.7 \\
\hline$x_{31}$ & 360.91 & 380.0 & 0.950 & 0.210 & 21.0 \\
\hline$x_{41}$ & 53.31 & 56.0 & 0.952 & 0.211 & 21.1 \\
\hline$x_{51}$ & 35.25 & 45.0 & 0.850 & 0.187 & 18.7 \\
\hline$\Sigma$ & & & 4.522 & 1.0 & 100.0 \\
\hline$C_{1}^{0}$ & & & 0.904 & & \\
\hline
\end{tabular}

Comprehensive assessment of the economic state of the municipality $C_{1}^{0}=0.904$, i.e. it reached the reference state by $90.4 \%$ for this block of indicators. However, per capita volume of gross domestic product by $21.5 \%$ provides achieved the state; the number of small businesses $-17.7 \%$; per capita investment in the real sector of the economy - by $21.0 \%$; per capita consolidated budget $21.1 \%$; the average monthly wage by $18.7 \%$.

Table 7. Calculation of the integrated assessment of investment attractiveness of a municipality.

\begin{tabular}{|c|c|c|c|c|c|}
\hline$C_{k}$ & $C_{k}^{0}$ & $C_{k}^{*}$ & $\alpha_{k}=\frac{C_{k}^{0}}{C_{k}^{*}}$ & $\beta_{k}=\frac{\alpha_{k}}{\sum_{j=1}^{m} \alpha_{k}}$ & $\begin{array}{c}\beta_{j 2}(\%) \\
\text { importance }\end{array}$ \\
\hline
\end{tabular}




\begin{tabular}{|c|c|c|c|c|c|}
\hline & & & & & \\
\hline$C_{1}^{0}$ & 0.904 & 1 & 0.904 & 0.328 & 32.8 \\
\hline$C_{2}^{0}$ & 0.921 & 1 & 0.921 & 0.335 & 33.5 \\
\hline$C_{3}^{0}$ & 0.927 & 1 & 0.927 & 0.337 & 33.7 \\
\hline$\Sigma$ & & & 2.752 & 1.0 & 100.0 \\
\hline$C^{0}$ & & & 0.917 & & \\
\hline
\end{tabular}

Integrated assessment of the investment attractiveness of the municipality for the entire complex of blocks $C^{0}=0.917$, i.e. it reached the reference state by $91.7 \%$ for the entire set of indicators. The economic condition of $32.8 \%$ achieve the benchmark of the investment attractiveness; social issues $-33.5 \%$; environmental condition - by $33.7 \%$.

Let's combine all the calculation results into a single table 8 .

Table 8. Interpretation of investment attractiveness of a municipality

\begin{tabular}{|c|c|c|c|c|c|}
\hline $\begin{array}{c}\text { Integrated } \\
\text { assessment } \\
\text { of } \\
\text { investment } \\
\text { attracti- } \\
\text { veness } \\
\end{array}$ & Block & $\begin{array}{c}\text { Comp- } \\
\text { rehensive } \\
\text { assess- } \\
\text { ment }\end{array}$ & $\begin{array}{c}\text { Signifi- } \\
\text { cance, } \\
\%\end{array}$ & Economic status & Indicator \\
\hline \multirow{12}{*}{84.1} & \multirow[t]{5}{*}{$\begin{array}{l}\text { Economic } \\
\text { condition }\end{array}$} & \multirow[t]{5}{*}{90.4} & \multirow[t]{5}{*}{32,8} & $\begin{array}{l}\text { The average annual volume of } \\
\text { gross domestic product }\end{array}$ & 21.5 \\
\hline & & & & Number of small businesses & 17.7 \\
\hline & & & & $\begin{array}{l}\text { Average per capita investment in } \\
\text { the real economy }\end{array}$ & 21.0 \\
\hline & & & & Per capita consolidated budget & 21.1 \\
\hline & & & & Average monthly wage & 18.7 \\
\hline & \multirow{5}{*}{\begin{tabular}{|c} 
State of \\
the social \\
sphere
\end{tabular}} & \multirow[t]{5}{*}{92.1} & \multirow[t]{5}{*}{33.5} & Per capita trade turnover & 19.8 \\
\hline & & & & Per capita volume of paid services & 19.8 \\
\hline & & & & Per capita housing security & 19.9 \\
\hline & & & & $\begin{array}{l}\text { Per capita current expenditures on } \\
\text { social services }\end{array}$ & 19.3 \\
\hline & & & & $\begin{array}{c}\text { Average per capita investment } \\
\text { in the social sphere }\end{array}$ & 21.2 \\
\hline & \multirow[t]{2}{*}{$\begin{array}{l}\text { cological } \\
\text { state }\end{array}$} & \multirow[t]{2}{*}{92.7} & \multirow[t]{2}{*}{33.7} & $\begin{array}{l}\text { Per capita current environmental } \\
\text { expenditures }\end{array}$ & 49.9 \\
\hline & & & & $\begin{array}{l}\text { Per capita investment in } \\
\text { environmental protection }\end{array}$ & 50.1 \\
\hline
\end{tabular}

Calculations showed that $J_{p t}=84.1 ; J_{p r}=91.7$, then,

$$
J_{M}=\frac{J_{n p}}{J_{n m}}=\frac{91.7}{84.1}=1.09
$$

Thus, the level of motivation for the implementation of social responsibility of business is equal to 1.09 , which indicates that the business has full confidence in the implementation of its social responsibility to the territory of its deployment.

As for the significance of blocks and indicators in assessing the investment potential of a company and assessing the investment attractiveness of territory, affecting the indicators with a higher significance level, ceteris paribus, will grow faster as the level of investment potential of the company and the level of investment attractiveness of the territory. 


\section{Conclusion}

Summing up the above, we note that the issue of stimulating social responsibility of business remains open. Within the framework of the proposed paradigm, the growth of investment attractiveness of rural areas is ensured by realizing the investment potential of business. At the same time, it should be particularly noted the causal relationship between the investment potential of business and the investment attractiveness of the territory, the increase in the volume of investments by the business entity in the territory, ensuring its socio-economic development, including the growth of human capital that the business uses in its activities. Consequently, increasing the investment attractiveness of the territory affects the growth of the level of motivation for the implementation of social responsibility of business, thus ensuring the harmonious development of the business and the territory of its location.

\section{References}

1. N. Zaruba, N. Egorova, P. Kosinskij, E3S Web Conf., 15, 04003 (2017)

2. N. Egorova, N. Zaruba, K. Dusan, E3S Web Conf., 105, 02011 (2019)

3. N. Egorova, N. Zaruba, T. Jurzina, V. Tumin, E3S Web Conf., 105, 02001 (2018)

4. T.V. Kiseleva, V.G. Mikhailov, V.A. Karasev, IOP Conf. Series: Earth and Environmental Science, 50, 012013 (2016)

5. V.G. Mikhailov, S.M. Bugrova, Ju.S. Yakunina, A.K. Muromtseva, Ya.S. Mikhailova, Ugol, 9, 106 (2019)

6. M. Yazevich, O. Kalinina, O. Zhironkina, E3S Web Conf., 134, 03004 (2019)

7. N.A. Zaruba, Economics and Innovation Management, 3, 17 (2018)

8. O. Nikiforova, T. Yakushina, R. Mamedov, E3S Web Conf., 105, 04013 (2019)

9. P. Kosinskiy, V. Merkuriev, A. Medvedev, E3S Web Conf., 134, 03009 (2019)

10. T. Jurzina, N. Egorova, N. Zaruba, P. Kosinskij, E3S Web Conf., 21, 04010 (2017)

11. T.A. Yurzina, N.N. Egorova, Journal of Economy and entrepreneurship, 85:8-1, 380 (2017)

12. V.G. Mikhailov, S.M. Bugrova, Ju.S. Yakunina, A.K. Muromtseva, Ya.S. Mikhailova, Ugol, 9, 106 (2019)

12. T.V. Kiseleva, V.G. Mikhailov, G.S. Mikhailov, IOP Conf. Series: Earth and Environmental Science, 84, 012044 (2017)

13. N.V. Shalanov, A.A. Aletdinova, IOP Conf. Series: Journal of Physics, 1015, 032004 (2018)

14. N.V. Shalanov, Mathematical methods for the digital economy (NSTU, Novosibirsk, 2020) 